\title{
Analisis Proksimat dan Total Serat Pangan pada Crackers Fortifikasi Tepung Tempe dan Koleseom (Talinum tiangulare)
}

\author{
Proximate and Total Fibers Analysis on Crackers Fortified with Tempe and Kolesom Flour \\ (Talinum tiangulare) \\ Hermawan Seftiono*, Evelyn Djiuardi, Sherly Pricila \\ Program Studi Ilmu dan Teknologi Pangan, Fakultas Bioindustri, Universitas Trilogi, \\ Jl. TMP Kalibata No. 1, Kalibata-Jakarta Selatan, Indonesia \\ *Email: hermawan_seftiono@trilogi.ac.id
}

Tanggal submisi: 30 Oktober 2017; Tanggal penerimaan: 14 Mei 2019

\begin{abstract}
ABSTRAK
Kolesom (Talinum tiangulare) merupakan jenis sayuran yang memiliki kandungan serat pangan tinggi. Tempe termasuk makanan khas Indonesia yang mengandung protein tinggi dan dapat dijadikan sumber protein alternatif. Akan tetapi pemanfaatan daun kolesom dan tempe masih rendah. Salah satu cara untuk meningkatkan pemanfaatan kolesom dan tempe adalah dengan menambahkan tepung daun kolesom dan tempe untuk meningkatkan kandungan gizi crackers. Crackers merupakan salah satu jenis biskuit yang bertekstur renyah dan sering dijadikan sebagai camilan. Penambahan tepung tempe dan tepung daun kolesom juga diharapkan dapat meningkatkan kandungan protein dan serat pangan crackers. Tujuan penelitian ini adalah untuk menentukan formulasi dan menguji proksimat dari crackers yang difortifikasi menggunakan tepung tempe dan tepung kolesom. Tepung tempe memiliki kadar protein sebesar 49,08\%, serta kadar total serat pangan tepung kolesom sebesar 19,22\%. Penentuan crackers terbaik berdasarkan tingkat kesukaan panelis pada uji organoleptik. Presentase kesukaan tertinggi secara keseluruhan terdapat pada crackers F5 (T10\%+K2.5g), yang mengandung kadar air sebesar 4,81\%, kadar abu 2,53\%, lemak total $18,43 \%$, protein $11,90 \%$, karbohidrat total $62,33 \%$, dan total serat pangan $8,29 \%$.
\end{abstract}

Kata kunci: Crackers; serat pangan; daun kolesom; proksimat; tepung tempe

\begin{abstract}
Kolesom is a vegetable which contains a high dietary fiber content. Tempe is an Indonesian food that contains high protein and can be an alternative protein source. However, both tempe and kolesom haven't been widely utilized. One way to improve the utilization is by adding kolesom and tempe flour to increase the nutrient content of crackers. Crackers are one type of crunchy-textured biscuits and are often consumed as a snack. The addition of tempe flour and kolesom flour are also expected to increase protein and dietary fiber content of crackers. This research was aimed to determine the best formulation and proximate level of crackers fortified with tempe and kolesom flour. Cracker production began with the manufacture of tempe flour which has a protein content of $49.08 \%$ and kolesom flour which has a total dietary fiber content of $19.22 \%$. Determination of the best crackers based on panelists' preferences was based on organoleptic test. The highest overall percentage of preference was found in $\mathrm{F} 5$ crackers $(\mathrm{T} 10 \%+\mathrm{K} 2.5 \mathrm{~g})$, containing $4.81 \%$ moisture content, $2.53 \%$ ash content, $18.43 \%$ total fat, $11.90 \%$ protein, $62.33 \%$ total carbohydrate, and total dietary fiber $8.29 \%$.
\end{abstract}

Keywords: Crackers; dietary fiber; kolesom leaf; proximate; tempe flour 


\section{PENDAHULUAN}

Crackers merupakan salah satu jenis pangan yang termasuk ke dalam kategori biskuit dan sering dikonsumsi sebagai makanan camilan. Cracker memiliki tekstur renyah dan umur simpan yang lama dari beberapa minggu bahkan berbulan-bulan karena kandungan kadar air yang rendah (Sirpatrawan, 2009). Umumnya produk crackers yang ada di pasaran mengandung karbohidrat yang tinggi karena bahan baku utamanya berupa tepung terigu. Kondisi saat ini pada masyarakat perkotaan dengan aktivitas yang padat menyebabkan mereka kekurangan asupan nutrisi berupa protein dan serat pangan (Novasari 2016; Santoso 2011). Oleh sebab itu penelitian ini berupaya memenuhi kebutuhan nutrisi berupa protein dan serat melalui produk crackers. Pemenuhan asupan nutrisi khususnya protein dirasa masih terkendala dikarenakan tingginya harga produk protein hewani, sehingga perlu alternatif yaitu protein nabati. Crackers yang dibuat dengan menambahkan sumber protein dari tepung tempe dan sumber serat dari tepung kolesom. Pemilihan tepung tempe dan tepung kolesom dikarenakan bahan baku lokal ini masih sedikit dimanfaatkan.

Tempe merupakan salah satu produk protein nabati yang tinggi kandungan proteinnya, namun makanan tradisional khas Indonesia ini memiliki kekurangan yaitu umur simpan yang tidak lama (Lastriyanto dkk., 2016). Oleh sebab itu tempe perlu diolah kembali menjadi tepung tempe agar meningkatkan umur simpannya (Bastian dkk., 2013). Penelitian Asyafullah (2015) menunjukkan bahwa tepung tempe memiliki kadar protein tinggi yaitu $51.73 \%$ (b/b) dibandingkan dengan tepung kedelai yang direbus hanya $51.06 \%$ (b/b). Berdasarkan hasil penelitian Fadhilatunnur (2013), dari berbagai jenis sayuran, daun kolesom mengandung serat pangan tertinggi yaitu 73.04-78.74 g/100 g basis kering. Kandungan serat pangan dan pektin yang terdapat pada daun kolesom dapat membantu mengurangi kekerasan feses, meningkatkan mikroflora usus dan menurunkan kadar Low Density Lipoprotein (LDL) dalam darah (Cui, 2005). Penelitian ini bertujuan untuk menganalisis kandungan proksimat pada crackers yang difortifikasi tepung tempe dan tepung kolesom dalam upaya meningkatkan kadar protein dan serat pada produk crackers sehingga kebutuhan protein dan serat dapat terpenuhi.

\section{METODE PENELITIAN}

\section{Bahan dan Peralatan}

Bahan-bahan utama yang digunakan antara lain tempe yang berasal dari UKM tempe di daerah pancoran
Jakarta Selatan, daun kolesom berasal dari kebun di daerah kedunghalang Bogor, tepung terigu (soft flour dengan kandungan protein 8-9\%), susu skim, margarine, baking soda, ragi roti (instant yeast), garam, mentega dan air. Peralatan-peralatan yang digunakan diantaranya, dehidrator, oven, tanur, desikator, food processor, cawan porselen, perangkat Soxhlet, perangkat Kjeldahl, dan peralatan gelas lainnya.

\section{Pembuatan Tepung Tempe}

Proses pembuatan tepung tempe dilakukan menggunakan metode Inayati 1991 dengan modifikasi. Prosesnya melalui tahap-tahap pemotongan tempe segar, pengukusan dengan uap, pengeringan dengan dehidrator (dimodifikasi), penggilingan dan pengayakkan. Tempe dipotong dengan ketebalan 0,5 $\mathrm{cm}$. Berdasarkan hasil penelitian bahwa pengukusan selama 10 menit pada suhu $176^{\circ} \mathrm{F}\left(80^{\circ} \mathrm{C}\right)$ menggunakan pengukus serta dengan pengeringan dengan dehidrator selama 4-4,5 jam pada suhu $176^{\circ} \mathrm{F}\left(80^{\circ} \mathrm{C}\right)$.

\section{Pembuatan Tepung kolesom}

Pembuatan tepung daun kolesom menggunakan metode Fadhilatunnur (2013) dengan modifikasi. Pembuatan tepung melalui beberapa tahapan. Pertama, daun kolesom dipisahkan dari rantingnya kemudian dicuci dengan air bersih untuk menghilangkan kotoran yang menempel pada daun. Selanjutnya, daun kolesom disusun dalam tray dan dikeringkan dalam alat dehidrator (dimodifikasi) selama 17 jam pada suhu $140{ }^{\circ} \mathrm{F}\left(160^{\circ} \mathrm{C}\right)$. Daun yang sudah kering kemudian dihancurkan dengan food processor sampai halus. Tepung daun kolesom yang sudah jadi disimpan didalam plastik kedap udara.

\section{Proses pembuatan crackers}

Proses pembuatan crackers berbasis tepung tempe dan tepung kolesom meliputi proses pencampuran bahan, proses fermentasi, proses pembuatan lembaran, proses pemanggangan. Tahapan proses pembuatan crackers dimulai dengan mencampurkan bahan pada Tabel 1 seperti tepung tempe, tepung daun kolesom, tepung tempe, susu skim, ragi, air, garam, margarin, dan lemak korsvet, menggunakan mixer lalu dicampur dengan tangan hingga kalis. Kemudian ditaruh dalam wadah dan ditutup lap basah untuk fermentasi selama 1 jam. Selanjutnya adonan dibuat lembaran, dilipat menjadi dua bagian, ditaburi tebung daun kolesom, dan digiling kembali menjadi lembaran. Setelah itu adonan dicetak dan dipanggang dalam oven hingga kering. 
Tabel 1. Formula cracker dengan penambahan tepung cracker dan tepung kolesom

\begin{tabular}{|c|c|c|c|c|c|c|c|c|c|c|c|c|c|}
\hline \multirow{5}{*}{ Bahan-bahan } & \multirow{5}{*}{ Kontrol } & \multicolumn{12}{|c|}{ Tepung tempe (g) dan tepung kolesom ( $\mathrm{g}$ ) } \\
\hline & & \multicolumn{3}{|c|}{7,5} & \multicolumn{3}{|c|}{10} & \multicolumn{3}{|c|}{12,5} & \multicolumn{3}{|c|}{15} \\
\hline & & 2,5 & 5,0 & 7,5 & 2,5 & 5,0 & 7,5 & 2,5 & 5 & 7,5 & 2,5 & 5 & 7,5 \\
\hline & & $\mathrm{T} 7,5$ & $\mathrm{~T} 7,5$ & $\mathrm{~T} 7,5$ & $\mathrm{~T} 10$ & $\mathrm{~T} 10$ & $\mathrm{~T} 10$ & $\mathrm{~T} 12,5$ & $\mathrm{~T} 12,5$ & $\mathrm{~T} 12,5$ & T15 & $\mathrm{T} 15$ & $\mathrm{~T} 15$ \\
\hline & & $+\mathrm{K} 2,5$ & $+\mathrm{K} 5$ & $+\mathrm{K} 7,5$ & $+\mathrm{K} 2,5$ & $+\mathrm{K} 5$ & $+\mathrm{K} 7,5$ & $+\mathrm{K} 2,5$ & $+\mathrm{K} 5$ & $+\mathrm{K} 7,5$ & $+\mathrm{K} 2,5$ & $+\mathrm{K} 5$ & $+K 7,5$ \\
\hline Tepung terigu & 100 & 92,50 & 92,50 & 92,50 & 90,00 & 90,00 & 90,00 & 87,50 & 87,50 & 87,50 & 85,00 & 85,00 & 85,00 \\
\hline Tepung tempe & 0,00 & 7,50 & 7,50 & 7,50 & 10,00 & 10,00 & 10,00 & 12,50 & 12,50 & 12,50 & 15,00 & 15,00 & 15,00 \\
\hline $\begin{array}{l}\text { Tepung } \\
\text { kolesom }\end{array}$ & 0,00 & 2,50 & 5,00 & 7,50 & 2,50 & 5,00 & 7,50 & 2,50 & 5,00 & 7,50 & 2,50 & 5,00 & 7,50 \\
\hline Susu skim & 4,00 & 4,00 & 4,00 & 4,00 & 4,00 & 4,00 & 4,00 & 4,00 & 4,00 & 4,00 & 4,00 & 4,00 & 4,00 \\
\hline Margarin & 20,00 & 20,00 & 20,00 & 20,00 & 20,00 & 20,00 & 20,00 & 20,00 & 20,00 & 20,00 & 20,00 & 20,00 & 20,00 \\
\hline Mentega & 10,00 & 10,00 & 10,00 & 10,00 & 10,00 & 10,00 & 10,00 & 10,00 & 10,00 & 10,00 & 10,00 & 10,00 & 10,00 \\
\hline Gula & 1,00 & 1,00 & 1,00 & 1,00 & 1,00 & 1,00 & 1,00 & 1,00 & 1,00 & 1,00 & 1,00 & 1,00 & 1,00 \\
\hline Garam & 2,20 & 2,20 & 2,20 & 2,20 & 2,20 & 2,20 & 2,20 & 2,20 & 2,20 & 2,20 & 2,20 & 2,20 & 2,20 \\
\hline Baking powder & 0,20 & 0,20 & 0,20 & 0,20 & 0,20 & 0,20 & 0,20 & 0,20 & 0,20 & 0,20 & 0,20 & 0,20 & 0,20 \\
\hline Ragi & 2,00 & 2,00 & 2,00 & 2,00 & 2,00 & 2,00 & 2,00 & 2,00 & 2,00 & 2,00 & 2,00 & 2,00 & 2,00 \\
\hline Air & 34,00 & 34,00 & 34,00 & 34,00 & 34,00 & 34,00 & 34,00 & 34,00 & 34,00 & 34,00 & 34,00 & 34,00 & 34,00 \\
\hline Total adonan & 173,40 & 175,9 & 178,4 & 180,9 & 175,9 & 178,4 & 180,9 & 175,9 & 178,4 & 180,9 & 175,9 & 178,4 & 180,9 \\
\hline
\end{tabular}

\section{Uji Organoleptik}

Uji organoleptik menggunakan metode dari Setyaningsih dkk. (2010) berupa uji hedonik dengan melibatkan 20 orang panelis semi terlatih. Atribut yang dinilai berupa aroma, rasa, warna, tekstur dan aftertaste. Penilaian menggunakan metode skala garis 1 sampai 7 yang merupakan tingkat kesukaan panelis. Mulai dari skala 1 yang menunjukkan "sangat tidak suka" hingga 7 yang menunjukkan "sangat suka". Panelis dianggap menerima produk jika nilai yang diberikan lebih besar dari 4 dilakukan pada 13 formulasi crackers yang sudah siap dimakan. Formula terbaik ditentukan berdasarkan hasil rata-rata uji hedonik tertinggi yaitu dengan melihat presentase penerimaan setiap formula. Formula terpilih inilah yang akan digunakan pada penelitian selanjutnya yaitu analisis proksimat dan total serat pangan.

\section{Analisis Kimia}

Analisis kimia yang dilakukan pada cracker meliputi penentuan kadar air dengan metode termogravimetri, kadar abu dengan metode penagbuan langsung, kadar protein total dengan mikro-kjeldhal, kadar lemak total dengan metode ekstraksi soxhlet, dan kadar karbohidrat dengan metode by difference (AOAC, 2005). Selain itu analisi total serat pangan, serat pangan tidak larut, dan anlisis serat pangan larut metode by difference (AOAC, 2005).

\section{Analisis Statistik dan Perhitungan Kalori}

Data yang di replikasi sebanyak 2 kali setelah diperoleh lalu diolah menggunakan Statistical product and service solution (SPSS) 23. Data hasil uji proksimat dianalisis secara statistik dengan uji independent $t$-test. Pendekatan perhitungan total kalori kalori dapat dilihat pada Persamaan 1.

Total kalori $=(4 \times \mathrm{KP})+(4 \times \mathrm{KK})+(9 \times \mathrm{KL})$

Keterangan:

$\mathrm{KP}=$ kadar protein $(\mathrm{g})$

$\mathrm{KK}=$ kadar karbohidrat $(\mathrm{g})$

$\mathrm{KL}=$ kadar lemak $(\mathrm{g})$

\section{HASIL DAN PEMBAHASAN}

\section{Kadar Protein Tepung Tempe}

Analisis kadar protein tepung tempe diperoleh hasil sebesar 49,08\% protein dari $100 \mathrm{~g}$ tepung tempe. Kadar protein tepung tempe yang tinggi berpotensi sebagai penyumbang protein pada crackers. Bila dibandingkan dengan penelitian lain diantaranya penelitian Rosyidah (2014) dengan kadar protein 48\%, penelitian Bastian dkk (2013) dengan kadar protein $46 \%$, dan penelitian Ichsani (2013) dengan kadar protein $52,7 \pm 1,14 \%$. Menurut Astawan dkk. (2013) kadar protein tempe 
berkisar 46,68 $-52,70 \%$. Perbedaan variasi kadar protein tepung tempe pada setiap penelitian dapat disebabkan oleh perbedaan proses pembuatan tempe, jenis kemasan tempe dan prosedur pembuatan tepung kedelai. Menurut Mukhoyaroh (2015) faktor yang mempengaruhi kadar protein antara lain lama pemeraman dan suhu pemeraman tempe. Selain itu penelitian Salim dkk. (2017) menunjukkan bahwa jenis kemasan berpengaruh terhadap kadar protein tempe.

\section{Serat PanganTepung Daun Kolesom}

Tepung daun kolesom (Talinum triangulare (Jacq.) Willd) yang dihasilkan dalam penelitian ini berwarna hijau tua, tekstur halus dengan berukuran 100 mesh (Gambar 1). Tepung daun kolesom ini diharapkan dapat berkontribusi terhadap kadar serat pangan. Berdasarkan kelarutannya, serat pangan dibagi menjadi serat pangan larut dan serat pangan tidak larut. Hasil analisis diperoleh kadar serat pangan tepung daun kolesom sebesar $3,49 \%$ serat pangan larut, $15,74 \%$ serat pangan tak larut, dan total serat pangan sebesar 19,22\% (Tabel 2). Manfaat serat pangan, diantaranya dapat mengontrol berat badan, memberikan rasa kenyang lebih lama, dan juga dapat mengurangi kadar kolesterol dengan cara mengikat lemak dalam usus halus

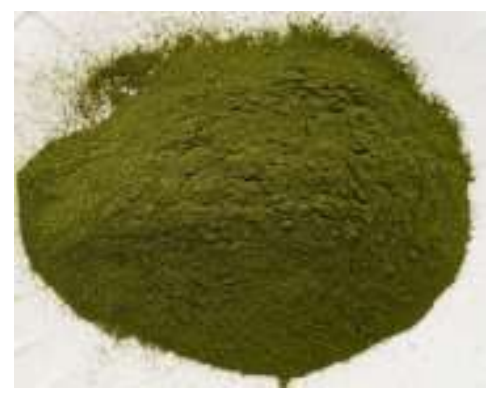

Gambar 1. Tepung daun kolesom

Tabel 2. Kandungan serat pangan tepung daun kolesom

\begin{tabular}{llll}
\hline No & Parameter & Satuan & Hasil \\
\hline 1. & Serat pangan larut & $\%$ & $3,49 \pm 0,0495$ \\
2. & Serat pangan tak larut & $\%$ & $15,74 \pm 0,0495$ \\
3. & Total serat pangan & $\%$ & $19,22 \pm 0,0495$ \\
\hline
\end{tabular}

\section{Karakteristik Organoleptik Crackers}

Uji organoleptik digunakan untuk menentukan formula terbaik, mengetahui daya terima, dan kesukaan panelis. Produk crackers tersebut diamati beberapa parameter seperti warna, aroma, rasa, tekstur, dan keseluruhan. Berdasarkan hasil uji organoleptik tehadap
Tabel 3. Nilai rata-rata hasil uji hedonik crackers fortifikasi tepung tempe dan tepung kolesom

\begin{tabular}{llllll}
\hline \multirow{2}{*}{ Formula } & \multicolumn{5}{c}{ Hedonik } \\
\cline { 2 - 6 } & Tekstur & Aroma & Warna & Rasa & Keseluruhan \\
\hline F3 & $4.85_{\mathrm{a}}$ & $4.45_{\mathrm{a}}$ & $4.35_{\mathrm{a}}$ & $4.85_{\mathrm{a}}$ & $4.10_{\mathrm{a}}$ \\
F5 & $5.00_{\mathrm{a}}$ & $4.50_{\mathrm{a}}$ & $4.25_{\mathrm{a}}$ & $4.70_{\mathrm{a}}$ & $4.75_{\mathrm{a}}$ \\
F8 & $4.35_{\mathrm{a}}$ & $4.20_{\mathrm{a}}$ & $4.70_{\mathrm{a}}$ & $4.65_{\mathrm{a}}$ & $4.30_{\mathrm{a}}$ \\
\hline
\end{tabular}

Angka-angka pada kolom yang sama yang diikuti oleh huruf yang sama menunjukkan hasil yang tidak berbeda nyata.

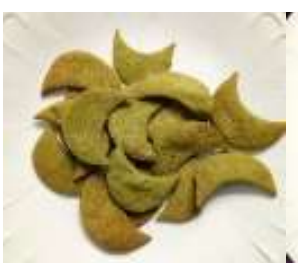

(a)

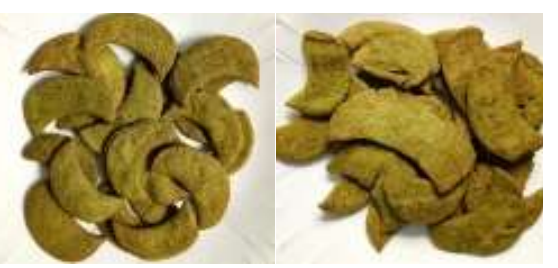

(b) (c)
Gambar 2. Formula crackers terpilih (a) F5 $(\mathrm{T} 10+\mathrm{K} 2,5)$, (b) F3 (T7,5+K5), (c) F8 (T12,5+K2,5)

12 formulasi, diperoleh crackers yang paling disukai panelis secara berurutan yaitu F5 (T 10\% + K 2,5 g), F3 (T 7,5\% + K $5 \mathrm{~g})$ dan F8 (T 12,5\% + K 2,5 g).

Pengujian organoleptik yang dilakukan panelis terhadap parameter tekstur, aroma, warna, rasa dan aftertaste memiliki nilai yang tidak berbeda nyata yang diberikan oleh panelis terhadap tiga formulasi terbaik. Skor yang diberikan oleh panelis terhadap tiga formulasi terbaik berkisar antara 4,10-5,00 yang berada pada kisaran tingkat kesukaan netral hingga suka. Formula F5 memiliki skor tertinggi diantara F3 dan F8 dalam beberapa parameter yaitu tekstur dengan nilai 5,00 , aroma 4,50 dan after taste 4,75 (Tabel 3). Formula F8 dengan penambahan tepung tempe yang lebih tinggi yaitu $12,5 \%$ menyebabkan nilai tekstur, aroma dan rasa yang lebih rendah hal ini menunjukkan bahwa panelis kurang menyukai penambahan tepung tempe yang berlebih sedangkan penambahan tepung kolesom yang lebih tinggi yaitu $5 \mathrm{~g}$ pada formula F3 menyebabkan penilaian warna lebih rendah yang menunjukkan panelis tidak menyukai penambahan tepung kolesom yang berlebih.

\section{Sifat Kimia Crackers}

Analisis sifat kimia dilakukan terhadap formula terpilih yaitu F5, F3, dan F8 dan juga kontrol. Sifat kimia yang dianalisis meliputi kadar air, abu, protein, lemak, karbohidrat, dan serat pangan. Hasil uji independent $t$-test menunjukkan adanya perbedaan atau tidak antara 
Tabel 4. Sifat kimia crackers dengan penambahan tepung tempe dan kolesom

\begin{tabular}{|c|c|c|c|c|}
\hline Parameter & $\begin{array}{l}\text { Kontrol } \\
(\mathrm{TO}+\mathrm{K} 0)\end{array}$ & $\begin{array}{l}\mathrm{F} 3 \\
(\mathrm{~T} 7,5 \mathrm{~g}+\mathrm{K} 5 \mathrm{~g})\end{array}$ & $\begin{array}{l}\mathrm{F} 5 \\
(\mathrm{~T} 10 \mathrm{~g}+\mathrm{K} 2,5 \mathrm{~g})\end{array}$ & $\begin{array}{l}\mathrm{F} 8 \\
(\mathrm{~T} 12,5 \mathrm{~g}+\mathrm{K} 2,5 \mathrm{~g})\end{array}$ \\
\hline $\begin{array}{l}\text { Kadar air (\%) } \\
\text { Nilai } p \text { (uji T dengan F5) }\end{array}$ & $\begin{array}{l}3,94 \pm 0,0778 \\
p<0,05\end{array}$ & $\begin{array}{l}4,93 \pm 0,0849 \\
p>0.05\end{array}$ & $4,81 \pm 0,0424$ & $\begin{array}{l}5,56 \pm 0,0707 \\
p<0,05\end{array}$ \\
\hline $\begin{array}{l}\text { Kadar abu (\%) } \\
\text { Nilai } p \text { (uji T dengan F5) }\end{array}$ & $\begin{array}{l}2,61 \pm 0,0495 \\
p>0,05\end{array}$ & $\begin{array}{l}2,79 \pm 0,0212 \\
p<0,05\end{array}$ & $2,53 \pm 0,0000$ & $\begin{array}{l}2,70 \pm 0,0566 \\
p>0,05\end{array}$ \\
\hline $\begin{array}{l}\text { Lemak total (\%) } \\
\text { Nilai } p \text { (uji T dengan F5) }\end{array}$ & $\begin{array}{l}19,95 \pm 0,2828 \\
p<0,05\end{array}$ & $\begin{array}{l}18,28 \pm 0,0849 \\
p>0,05\end{array}$ & $18,43 \pm 0,0566$ & $\begin{array}{l}19,91 \pm 0,0566 \\
p>0,05\end{array}$ \\
\hline $\begin{array}{l}\text { Protein (\%) } \\
\text { Nilai } p \text { (uji T dengan F5) }\end{array}$ & $\begin{array}{l}10,83 \pm 0,1414 \\
p<0,05\end{array}$ & $\begin{array}{l}11,32 \pm 0,1202 \\
p>0,05\end{array}$ & $11,90 \pm 0,1838$ & $\begin{array}{l}12,47 \pm 0,1414 \\
p>0,05\end{array}$ \\
\hline $\begin{array}{l}\text { Karbohidrat total (\%) } \\
\text { Nilai } p \text { (uji T dengan F5) }\end{array}$ & $\begin{array}{l}62,68 \pm 0,5515 \\
p>0,05\end{array}$ & $\begin{array}{l}62,69 \pm 0,0990 \\
p>0,05\end{array}$ & $62,33 \pm 0,1980$ & $\begin{array}{l}59.36 \pm 0,0778 \\
p<0,05\end{array}$ \\
\hline $\begin{array}{l}\text { Serat pangan larut (\%) } \\
\text { Nilai } p \text { (uji T dengan F5) }\end{array}$ & $\begin{array}{l}5,56 \pm 0,0424 \\
p<0,05\end{array}$ & $\begin{array}{l}5,33 \pm 0,0495 \\
p<0,05\end{array}$ & $6,33 \pm 0,0919$ & $\begin{array}{l}5,16 \pm 0,0636 \\
p<0,05\end{array}$ \\
\hline $\begin{array}{l}\text { Serat pangan tak larut (\%) } \\
\text { Nilai } p \text { (uji T dengan F5) }\end{array}$ & $\begin{array}{l}1,58 \pm 0,0354 \\
p<0,05\end{array}$ & $\begin{array}{l}2,42 \pm 0,0566 \\
p<0,05\end{array}$ & $1,96 \pm 0,0283$ & $\begin{array}{l}3,66 \pm 0,0495 \\
p<0,05\end{array}$ \\
\hline $\begin{array}{l}\text { Total serat pangan (\%) } \\
\text { Nilai } p \text { (uji T dengan F5) }\end{array}$ & $\begin{array}{l}7,14 \pm 0,0778 \\
p<0,05\end{array}$ & $\begin{array}{l}7,75 \pm 0,0071 \\
p<0,05\end{array}$ & $8,29 \pm 0,0636$ & $\begin{array}{l}8,81 \pm 0,1202 \\
p<0,05\end{array}$ \\
\hline Energi total (kkal) & $473.59 \pm 0.9051$ & $460.54 \pm 0.8485$ & $462.79 \pm 0.4525$ & $466.51 \pm 0.2263$ \\
\hline Nilai $p$ (uji T dengan F5) & $p<0.05$ & $p<0.05$ & & $p<0.05$ \\
\hline
\end{tabular}

perbandingan sampel terbaik yaitu $\mathrm{F} 5$ dengan sampel kontrol, F3, dan F8. Jika hasil uji independent t-test menunjukkan nilai $\mathrm{p}$ kurang dari 0.05 maka terdapat perbedaan nyata, sedangkan jika nilai $\mathrm{p}$ lebih dari 0.05 maka tidak terdapat perbedaan nyata antar sampel (Tabel 4).

\section{Kadar air}

Kadar air crackers terpilih yaitu F5 tidak berbeda nyata $(p>0,05)$ dengan crackers F3. Akan tetapi kadar air pada F5 berbeda nyata $(p<0,05)$ dengan kadar air crackers kontrol dan F8. Crackers F5 yang ditambahkan tepung tempe $10 \mathrm{~g}$ dan tepung daun kolesom 2,5 g memiliki kadar air yang lebih tinggi daripada kontrol (Gambar 3). Perbedaan nyata berdasarkan hasil uji t test pada crackers F5 dengan F8 diakibatkan oleh perbedaan penambahan jumlah tepung tempe yang ditambahkan, yaitu sebesar $12,5 \mathrm{~g}$ pada F8 dan $10 \mathrm{~g}$ pada F5. Sehingga dapat disimpulkan bahwa dengan penambahan tepung tempe dan tepung kolesom pada crackers akan meningkatkan kadar air crackers.

Berdasarkan SNI 2973-2011 tentang produk biskuit, kandungan air maksimal adalah sebesar $5 \%$, sehingga hanya crackers F5 dan F3 yang telah memenuhi standar SNI 2973-2011, namun berdasarkan penelitian Winarno (2004) kadar air 3-7\% dalam bahan pangan dapat mengurangi kemungkinan pertumbuhan mikroba dan reaksi kimia yang merusak seperti hidrolisis atau oksidasi lemak, sehingga crackers F8 yang mengandung kadar air sebesar $5,56 \%$ masih dapat diterima.

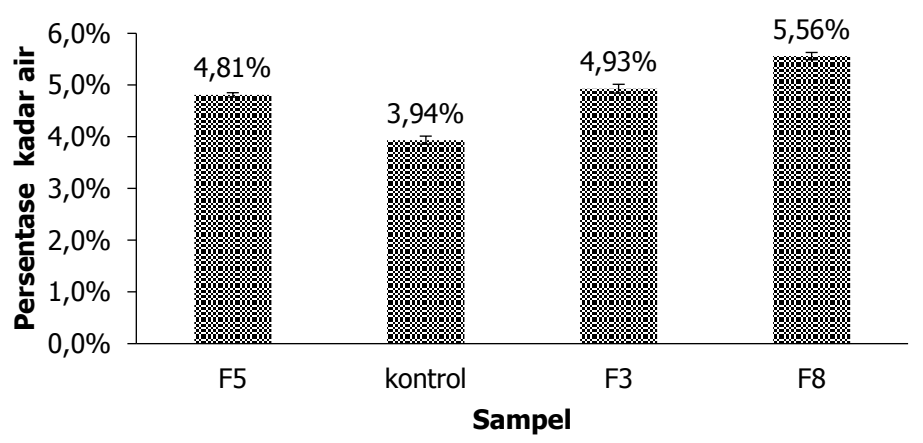

Gambar 3. Kadar air crackers 


\section{Kadar Abu}

Analisis kadar abu dilakukan untuk mengetahui kandungan mineral anorganik pada produk pangan dalam bentuk abu setelah melalui proses pembakaran dalam tanur. Semakin tinggi nilai kadar abu maka semakin tinggi kandungan bahan anorganik dalam produk tersebut (Bastian dkk., 2013). Uji independent T-test antara crackers F5 dengan kontrol dan F8 menunjukkan hasil kadar abu yang tidak berbeda nyata $(p>0,05)$, kecuali dengan crackers $F 3$ yang menunjukkan hasil kadar abu yang berbeda nyata $(p<0,05)$. Kadar abu tertinggi diperoleh dari crackers F3 dengan jumlah $2,79 \%$, lebih tinggi dari crackers terpilih F5, hal ini diduga karena kandungan kolesom pada F3 lebih tinggi daripada crackers lainnya yaitu sebanyak $5 \mathrm{~g}$ (Gambar 4).

Berdasarkan penelitian Mensah dkk. (2009) dalam $100 \mathrm{~g}$ daun kolesom memiliki beberapa kandungan mineral seperti kalsium (Ca) 2,44 mg, kalium (K) 6,10 $\mathrm{mg}$, magnesium $(\mathrm{Mg}) 2,22 \mathrm{mg}$, natrium $(\mathrm{Na}) 0.28 \mathrm{mg}$, dan besi (Fe) $0.43 \mathrm{mg}$. Kadar abu crackers fortifikasi tepung tempe dan tepung daun kolesom ini cukup tinggi bahkan melebihi kadar abu maksimum crackers menurut SNI 01-2973-1992 yaitu 2\%. Hal ini dapat disebabkan oleh perbedaan formulasi antara penelitian ini dan yang terdapat pada SNI. Tingginya kadar abu pada crackers menunjukkan bahwa kandungan mineral pada crackers tergolong tinggi.

\section{Kadar Lemak}

Lemak dalam pembuatan crackers berfungsi sebagai pembentuk cita rasa, pengemulsi, dan membentuk tekstur crackers. Berdasarkan SNI (1992) yang menyatakan bahwa crackers minimal mengandung kadar lemak 9,5\%. Ketiga formulasi serta kontrol terlah memuhi standar SNI dengan kadar lemak lebih dari 9,5\%. Hasil uji independent t-test menunjukan bahwa kadar lemak crackers terpilih yaitu F5 berbeda nyata $(p<0,05)$ dengan kadar lemak crackers kontrol dan F8, namun tidak berbeda nyata $(p>0,05)$ dengan kadar lemak crackers F3 (Gambar 5).

Kandungan lemak tertinggi terdapat pada crackers kontrol tanpa penambahan tepung tempe maupun kolesom yaitu sebesar $19.95 \%$ dan kandungan lemak terendah sebesar $18.28 \%$ terdapat pada crackers F3 yang diberikan penambahan tepung daun kolesom paling tinggi diantara 3 crackers lainnya yaitu sebanyak $5 \mathrm{~g}$, diduga bahwa semakin tinggi kandungan tepung kolesom pada crackers dapat menurunkan kadar lemak crackers dengan mengikat lemak yang ada pada bahan pangan.

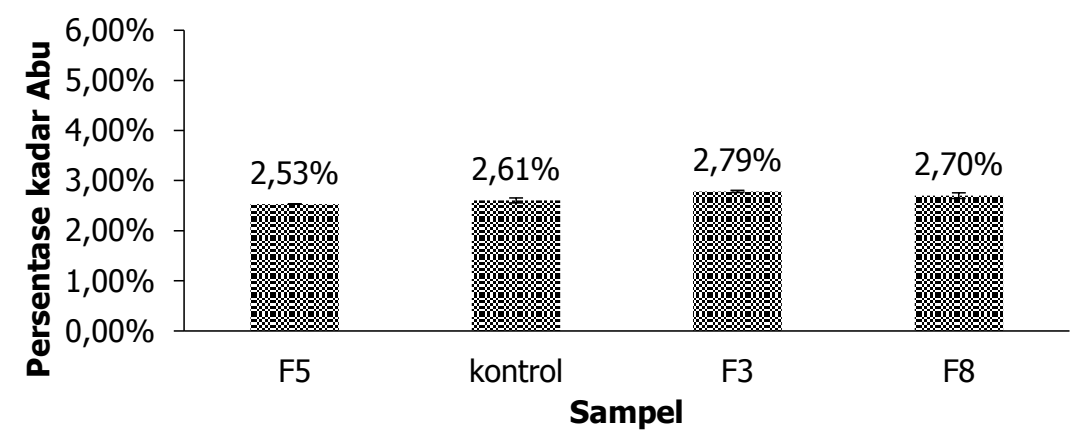

Gambar 4. Kadar abu crackers

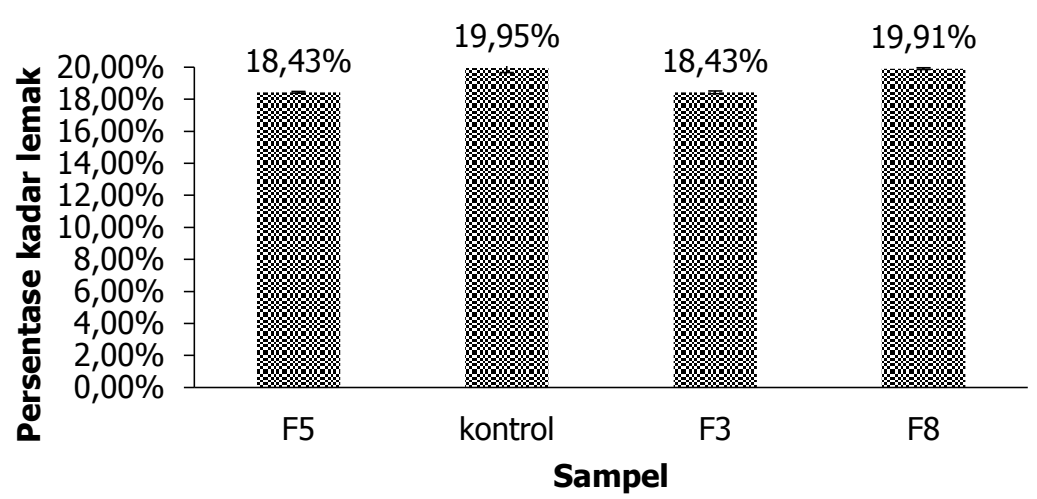

Gambar 5. Kadar lemak crackers 


\section{Kadar Protein}

Kadar protein crackers menunjukkan bahwa crackers terpilih yaitu F5 berbeda nyata $(p<0,05)$ dengan crackers kontrol, hal ini dikarenakan crackers kontrol tidak diberi penambahan tepung tempe dan kolesom sehingga kadar proteinnya rendah. Crackers F5 dengan penambahan tepung tempe $10 \%$ dan tepung daun kolesom 2,5 g mengandung protein 1,07\% lebih tinggi dibandingkan crackers kontrol tanpa penambahan tepung tempe maupun kolesom. Kadar protein crackers terpilih F5 tidak berbeda nyata $(p>0,05)$ dengan crackers F3 maupun F8. Crackers F5 mengandung protein 0,58\% lebih tinggi dibanding crackers F3 dengan penambahan tepung tempe $7,5 \mathrm{~g}$ dan tepung daun kolesom $5 \mathrm{~g}$. Sedangkan crackers F8 mengandung protein 0,57\% lebih tinggi dibanding crackers F5. Kadar protein tertinggi terdapat pada crackers F8 dengan kandungan protein sebesar 12,47\% (Gambar 6), hal ini disebabkan oleh jumlah penambahan tepung tempe paling banyak yaitu $12,5 \mathrm{~g}$ terdapat pada crackers F8. Penambahan tepung tempe pada produk crackers menyebabkan peningkatan kadar protein pada produk crackers. Seluruh crackers yang diuji telah memenuhi syarat mutu biskuit SNI 2973-2011 yaitu protein minimum sebesar 5\%.

\section{Kadar Karbohidrat}

Kadar karbohidrat crackers pada crackers F5, kontrol, F3, maupun F8 masing-masing bernilai $62,33 \%, 62,68 \%, 62,69 \%, 59,36 \%$. Hasil independent $t$ test menunjukkan kadar karbohidrat crackers terpilih yaitu F5 tidak berbeda nyata $(p>0,05)$ dengan crackers kontrol dan F3. Akan tetapi crackers F5 dengan crackers F8, kadar karbohidratnya berbeda nyata $(p<0,05)$, perbedaan nyata ini disebabkan oleh adanya penambahan tepung tempe sebagai sumber protein dengan kadar tertinggi sebanyak $12,5 \mathrm{~g}$ pada crackers F8, sehingga menyebabkan kadar karbohidrat crackers F8 lebih rendah dibandingkan crackers lainnya (Gambar 7).

\section{Kadar Serat Pangan Total}

Serat pangan dapat diperoleh dari tanaman namun tidak dapat dihidrolisis oleh enzim pencernaan. Kebutuhan serat yang dianjurkan yaitu sebesar $30 \mathrm{~g} / \mathrm{hari}$ (Santoso, 2011). Hasil independent $t$-test menunjukkan total serat pangan crackers terpilih $\mathrm{F} 5$ berbeda nyata $(p<0,05)$ dengan crackers kontrol, F3, dan F8. Crackers terpilih $\mathrm{F} 5$ dengan penambahan tepung tempe $10 \mathrm{~g}$ dan tepung daun kolesom 2,5 g mengandung total serat

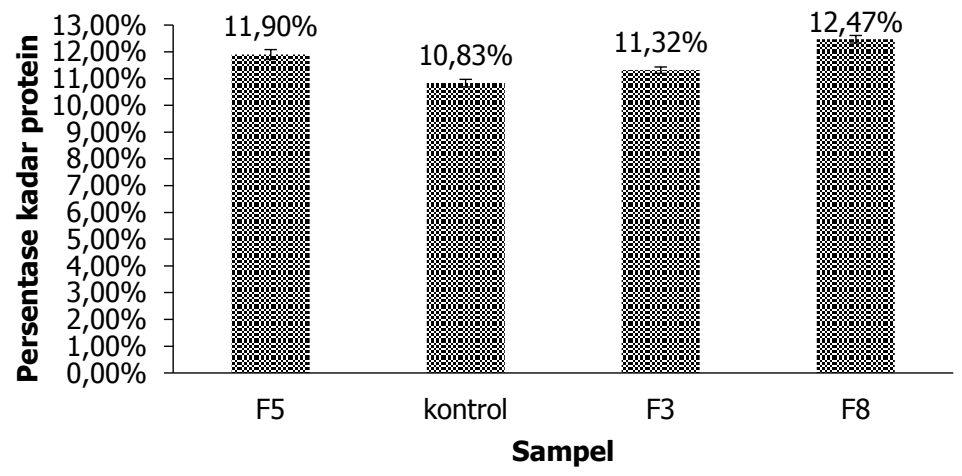

Gambar 6. Kadar protein crackers

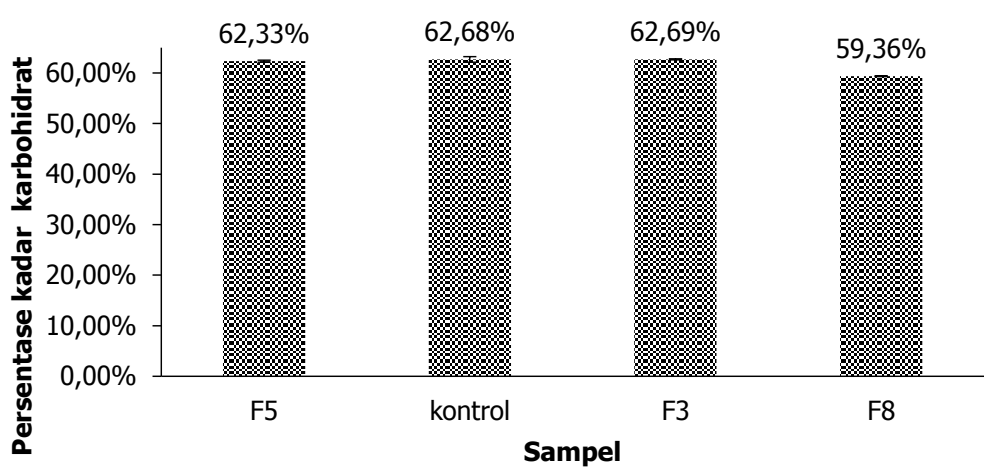

Gambar 7. Kadar karbohidrat crackers 


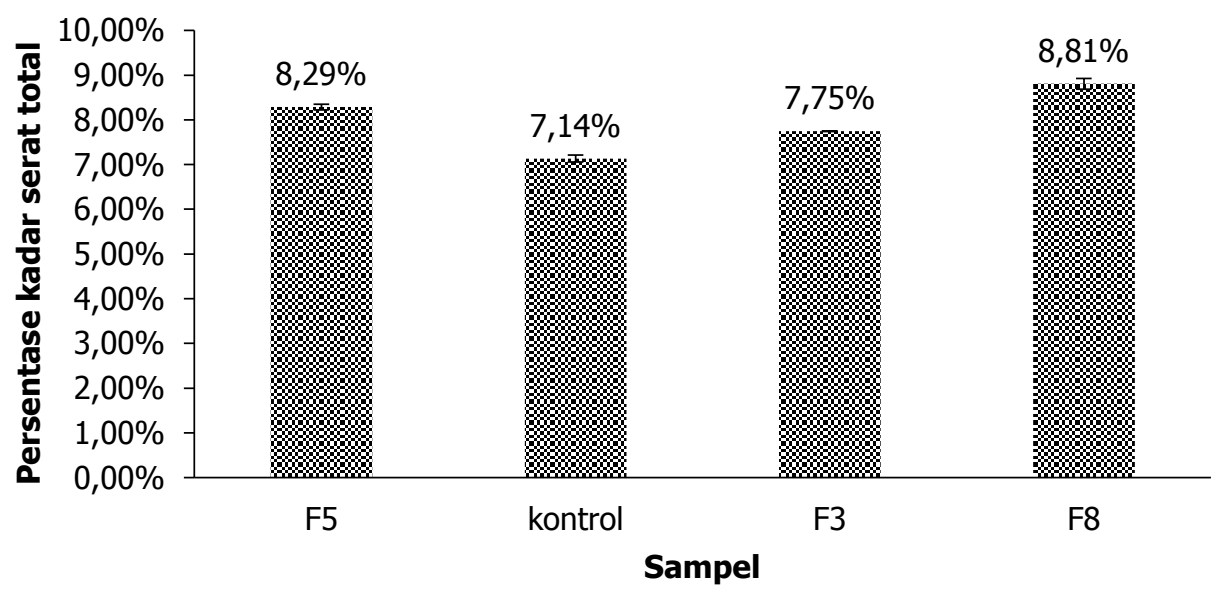

Gambar 8. Total serat pangan crackers

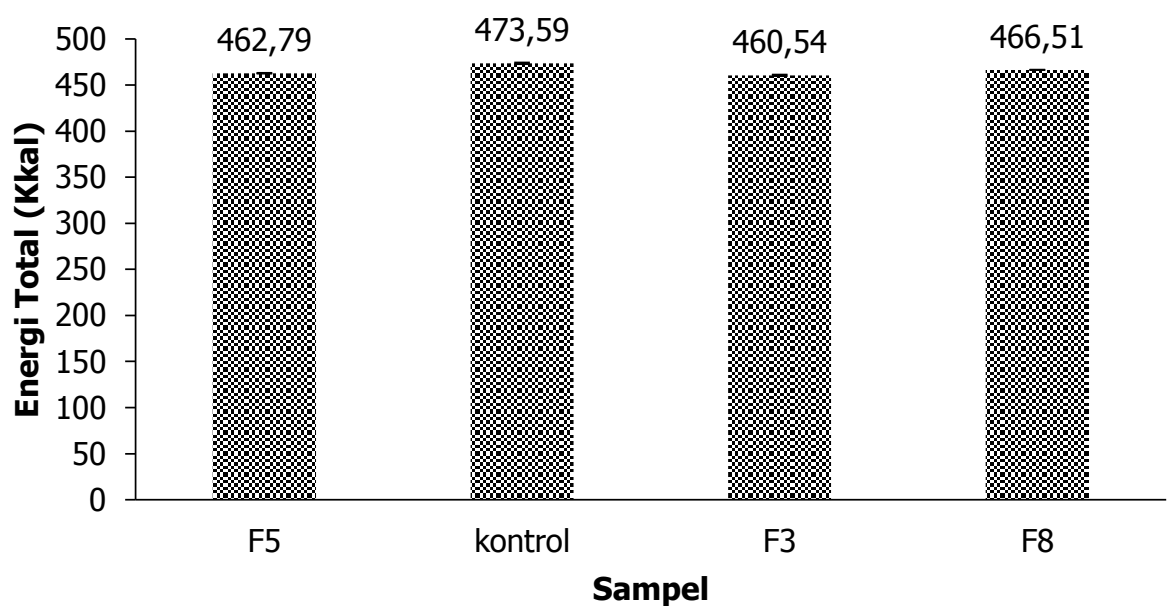

Gambar 9. Energi total crackers

pangan $1,15 \%$ lebih tinggi dibanding crackers kontrol tanpa penambahan tepung tempe maupun kolesom. Crackers F5 mengandung total serat pangan 0,54\% lebih tinggi dibandingkan crackers $\mathrm{F} 3$ yang ditambahkan dengan 7,5 $\mathrm{g}$ tepung tempe dan $5 \mathrm{~g}$ tepung daun kolesom. Kadar total serat pangan tertinggi terdapat pada crackers F8 dengan penambahan tepung tempe $12,5 \mathrm{~g}$ dan tepung daun kolesom $2,5 \mathrm{~g}$. Crackers F8 mengandung $0,52 \%$ total serat pangan lebih tinggi dibandingkan crackers F5 (Gambar 8).

Meskipun crackers F3 dilakukan penambahan tepung kolesom paling tinggi dibandingkan crackers lainnya yaitu sebesar $5 \mathrm{~g}$. Hasil analisis menunjukkan bahwa crackers F3 yang difortifikasi memiliki total serat pangan lebih rendah dibandingkan crackers lainnya. Hal ini diduga karena tidak hanya tepung daun kolesom yang menyumbangkan serat pangan, namun bahan penyusun lainnya seperti tepung tempe ataupun tepung terigu berperan dalam menyumbangkan serat pangan.

\section{Energi Total}

Kandungan energi biskuit dengan penambahan tepung daun kolesom dan tepung tempe diperoleh dengan mengkonversikan kadar protein, lemak, dan karbohidrat menjadi energi. Hasil uji independent $t$-test menunjukkan bahwa crackers terpilih F5 tidak berbeda nyata dengan crackers $\mathrm{F} 3$, namun berbeda nyata dengan crackers kontrol dan F8. Perbedaan ini disebabkan oleh tingginya kadar lemak pada crackers kontrol dan F8 sehingga sumbangan energi dari lemaknya pun lebih tinggi dibandingkan crackers lainnya (Gambar 9). Tingginya nilai energi total berasal dari tepung terigu, susu skim, margarine, dan mentega sebagai bahan penyusun crackers.

Energi yang dihasilkan dari crackers dengan penambahan tepung daun kolesom dan tepung tempe telah memenuhi syarat SNI mengenai kandungan energi pada biskuit terigu minimal 400 kkal per 100 g makanan. Berdasarkan AKG kebutuhan energi 2000 
kkal, crackers terpilih F5 memberikan kontribusi energi sebesar $23,3 \%$.

\section{KESIMPULAN}

Berdasarkan hasil uji organoleptik, formula terpilih adalah crackers $\mathrm{F} 5$ dengan penambahan tepung tempe $10 \mathrm{~g}$ dan tepung daun kolesom 2,5 g. Kandungan proksimat crackers terpilih yaitu kadar air 4,81\%, kadar abu 2,53\%, lemak total 18,43\%, protein $11,90 \%$, karbohidrat total $62,33 \%$, dan total serat pangan $8,29 \%$. Crackers terpilih menyumbangkan energi total sebesar 462,79 kkal per $100 \mathrm{~g}$. Penambahan tepung tempe dan kolesom pada formula F5 berpengaruh tehadap meningkatnya kadar protein dan total serat pangan pada crackers.

\section{UCAPAN TERIMA KASIH}

Ucapan terima kasih terutama ditujukan kepada program penelitian peningkatan kapasitas melalui SIMLITABMAS Pendanaan Tahun 2017.

\section{KONFLIK KEPENTINGAN}

Penulis menyatakan bahwa artikel ini asli, belum pernah dipublikasikan, dan bebas dari konflik kepentingan.

\section{DAFTAR PUSTAKA}

AOAC. (2005). Official Method of Analysis. Arlington: AOAC International.

Astawan, M., Wresdiyati, T., Widowati, S., Bintari, S. H., \& Ichsani, N. 2013. Karakteristik fisikokimia dan sifat fungsional tempe yang dihasilkan dari berbagai varietas kedelai. Pangan 22, (3): 241-252.

Asyafullah, K. (2015). Bioavailabilitas Mineral Kalsium dari Tepung Tempe dan Tepung Kedelai Rebus pada Tikus Percobaan. Institut Pertanian Bogor.

Bastian, F., Ishak, E., Tawali, B., \& Bilang, M. (2013). Daya terima dan kandungan zat gizi formula tepung tempe dengan penambahan semi refined carrageenan (SRC) dan bubuk kakao. Jurnal Aplikasi Teknologi Pangan, 2(1): 5-8.

BSN. (1992). Standar Nasional Indonesia. SNI 2973-1992. Biskuit. Jakarta: Badan Standarisasi Nasional.

BSN. (2011). Standar Nasional Indonesia. SNI 2973-2011.
Biskuit. Jakarta: Badan Standarisasi Nasional.

Cui, S. W. (2005). Food carbohydrates: chemistry, physical properties, and application. USA: CRC Press.

Fadhilatunnur, H. (2013). Analisis Perbandingan Kandungan Serat Pangan Kolesom (Talinum triangulare (Jacq.) Willd) dengan Pemupukkan Organik dan Anorganik pada Perbedaan Musim. Institut Pertanian Bogor.

Ichsani, N. (2013). Karakteristik Fisikokimia dan Sifat Fungsional Tempe yang Dihasilkan dari Berbagai Varietas Kedelai. Institut Pertanian Bogor.

Inayati, I. (1991). Biskuit Berprotein Tinggi dari Campuran Tepung Terigu, Singkong, dan Tempe Kedelai.Institut Pertanian Bogor.

Lastriyanto, A., Komar, N., \& Pratiwi, H. S. 2016. Pendugaan umur simpan pada penyimpanan dingin tempe kedelai (Glycine max (L.) Merill) dengan pengemasan vakum menggunakan model Arrhenius, Jurnal Keteknikan Pertanian Tropis dan Biosistem 4 (1): 75-86.

Mensah, J. K., R. I. Okoli, J. O. Ohaju-Obodo, \& K. Elfediyi. (2009). Phytochemical, nutritional and medicalproperties of some leafy vegetables consumed by Edo people in Nigeria. African Journal of Biotechnology .7(14): 23042309.

Mukhoyaroh, H. 2015. Pengaruh jenis kedelai, waktu dan suhu pemeraman terhadap kandungan protein tempe kedelai. Florea 2 (2): 47-51.

Novasari, V. (2017 Mei 27). Sepertiga Penduduk Indonesia Masih Kurang Asupan Protein.

Tribunnews. Diakses dari http://www.tribunnews.com/ tribunners/2016/05/27/sepertiga-penduduk-indonesiamasih-kurang-asupan-protein

Rosyidah, A. (2014). Substitusi Tepung Tempe Untuk Pembuatan Kue Lumpur Coklat Dengan Penambahan Variasi Gula Pasir. Universitas Muhammadiyah Surakarta.

Salim, R., Zebua, E.T., \& Taslim, T. 2017, Analisis jenis kemasan terhadap kadar protein dan kadar air pada tempe. 2 (2): 106-111. DOI: $10.22216 / j k . v 2 i 2.2531$

Santoso, A. (2011). Serat pangan (Dietary Fiber) dan manfaatnya bagi kesehatan. Magistra.75:35-40.

Sirpatrawan, U. (2009). Shelf-life simulation of packaged rice crackers. Journal of Food Quality. 32: 224239. DOI: $10.1111 /$ j.1745-4557.2009.00247.x

Setyaningsih, D., Apriyantono, A., \& Sari, M.P. 2010. Analisis Sensori untuk Industri Pangan dan Agro. Bogor: IPB Press.

Winarno, F. G. (2004). Kimia Pangan dan Gizi. Jakarta: Gramedia. 